Bradleya 30/2012

pages $19-24$

\title{
A new specific plant host for the agave snout weevil, Scyphophorus acupunctatus Gyllenhal, 1838 (Coleoptera: Curculionidae) in South Africa: a destructive pest of species of Agave L. (Agavaceae)
}

\author{
Gideon F. Smith ${ }^{1,2,4}$, Estrela Figueiredo ${ }^{3,4}$, Ronell R. Klopper ${ }^{1,2}$, Neil R. Crouch ${ }^{5}$, \\ Charlene Janion ${ }^{6}$ and Steven L. Chown 6 \\ ${ }^{1}$ Biosystematics Research and Biodiversity Collections, South African National Biodiversity Institute, \\ Private Bag X101, Pretoria, 0001 South Africa (email: G.Smith@sanbi.org.za; R.Klopper@ sanbi.org.za). \\ 2 H.G.W.J. Schweickerdt Herbarium, Department of Plant Science, University of Pretoria, Pretoria, 0002 \\ South Africa. \\ ${ }^{3}$ Department of Botany, P.O. Box 77000, Nelson Mandela Metropolitan University, Port Elizabeth, 6031 \\ South Africa (email: estrelafigueiredo@ hotmail.com). \\ ${ }^{4}$ Centre for Functional Ecology, Departamento de Ciências da Vida, Universidade de Coimbra, 3001-455 \\ Coimbra, Portugal. \\ ${ }^{5}$ Ethnobotany Unit, South African National Biodiversity Institute, P.O. Box 52099, Berea Road, 4007 \\ South Africa / School of Chemistry, University of KwaZulu-Natal, Durban, 4041 South Africa \\ (email: N.Crouch@sanbi.org.za). \\ ${ }^{6}$ Centre for Invasion Biology, Stellenbosch University, Private Bag X1, Matieland, 7602 South Africa \\ (email: cjanion@sun.ac.za; slchown@sun.ac.za).
}

Summary: The widely distributed agave snout weevil, Scyphophorus acupunctatus Gyllenhal, is for the first time recorded from Agave salmiana Otto ex Salm-Dyck subsp. salmiana in South Africa. In its native habitat in Mexico, this new host plant species is one of the most important sources of pulque, a fermented alcoholic beverage. With efforts underway at Bothaville in the Free State Province, South Africa, to establish an agave nectar industry, commercial farmers should be made aware of the destruction that the agave weevil can cause, especially in concentrated populations and plantations of Agave L. species.

Zusammenfassung: Der weit verbreitete AgavenRüsselkäfer Scyphophorus acupunctatus Gyllenhal wird zum ersten Mal für Agave salmiana Otto ex Salm-Dyck subsp. salmiana in Südafrika nachgewiesen. Die Heimat des Käfers ist Mexiko, und die neu nachgewiesene Wirtspflanze ist eine der wichtigsten Grundlagen für die Herstellung des alkoholischen Getränkes Pulque. Mit Blick auf die Versuche, in Bothaville in der Free State-Provinz, Südafrika, eine Agavensaft-Industrie aufzubauen, müssen die kommerziellen Pflanzer für die Schäden sensibilisiert werden, die der Käfer vor allem in dichten Populationen und Plantagen von Agave-Arten anrichten kann.

Introduction

Until recently, a tequila-like drink was distilled from the fermented hearts of Agave americana L. var. americana at Graaff-Reinet in the Eastern Cape (Stiemie, 1997; Biggs, 2004). This fledgling industry seemed to prosper, until the death of its director at the beginning of 2008, which ultimately resulted in its liquidation (Property24, 2008; Anon., 2009). It is anticipated that Karoobased plants of Agave L., targeted previously for the production of this alcoholic beverage, will continue to be harvested for their 'pinas' or central stem cores, from which a fructose-rich syrup is extracted and sold as a low GI food additive (sweetener). This natural sweetener is seen with increasing frequency in health shops in South Africa.

For more than a century Agavaceae species, especially A. sisalana Perrine ex Engelm., have also been commercially cultivated in South Africa for their fibres (Sutherland, 1900). As natural products have become increasingly popular, interest in this industry has been renewed 

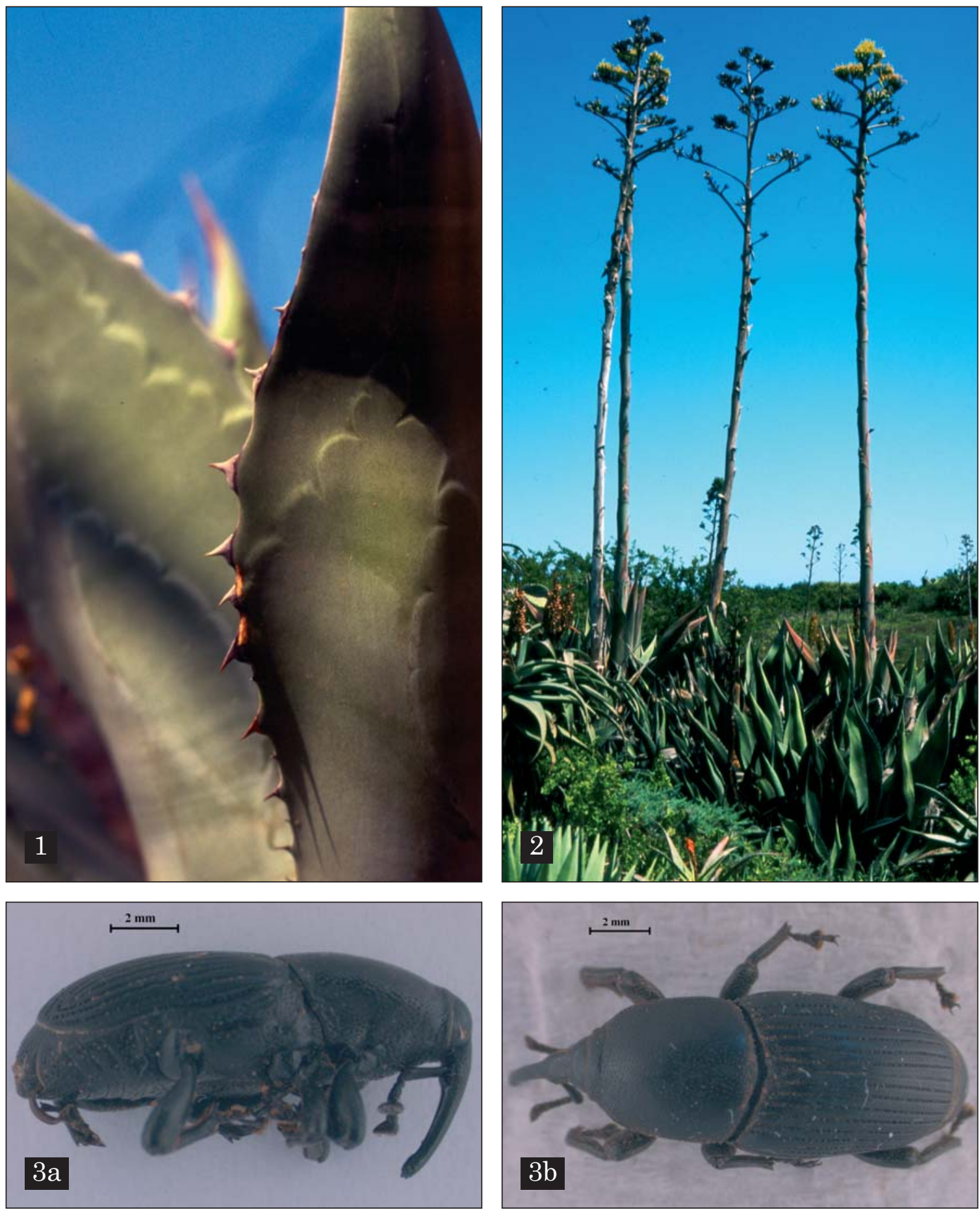

Figure 1. Agave salmiana subsp. salmiana is a large growing species of century plant from Mexico. Photo: Gideon F. Smith. Figure 2. The pyramid-shaped inflorescence of A. salmiana subsp. salmiana is carried on a thick robust pole. Photo: Gideon F. Smith. Figure 3. Lateral (a) and dorsal (b) view of the agave weevil (Scyphophorus acupunctatus Gyllenhal, Curculionidae). Voucher specimen [G.F. Smith \& E. Figueiredo 10] deposited at the Ditsong: National Museum of Natural History (formerly the Transvaal Museum), Pretoria. Photos: Charlene Janion. 
(Slabbert, 2007). It is likely that the genetic base of naturalized subpopulations of $A$. americana and $A$. sisalana is very narrow, such that effective pests in plantation situations could have severe impacts (see for example Smith \& Mössmer, 1996 on Agave americana in South Africa).

Several representatives of the families Agavaceae and Dracaenaceae are commonly used in ornamental and amenity horticulture, especially in countries that experience tropical, subtropical and mild-temperate climates. Material of these families is usually imported from tropical or subtropical countries in both the Old and New Worlds. Together with these imports often come unwelcome pests, particularly borers - insects that can significantly damage fibrous stems and trunks, as well as fleshy leaves. This is the case, for example, with the beetle Xyleborus ferrugineus Fabricius, 1801 (Coleoptera: Scolytidae) on Dracaena Vand. ex L. and Yucca L. and the yucca weevil, Yuccaborus frontalis LeConte, 1874 (Coleoptera: Curculionidae), on Yucca and Beaucarnea Lem. Both these pests have been recorded from plants imported to the Netherlands (EPPO, 2002).

One of the most damaging borers that attack plants of these families is the agave snout weevil, Scyphophorus acupunctatus Gyllenhal, 1838, a species that has spread from its original area of occurrence in Central America to other areas with tropical or subtropical climates. For instance, it was recently reported in the Guánica Dry Forest Reserve in southwestern Puerto Rico (Setliff \& Anderson, 2011), in Saint-Tropez, France (EPPO, 2008a; Germain et al., 2008), and previously in Italy (EPPO, 2008b). It has been known to occur on A. sisalana in South Africa and eastern Africa for some time (Verbeek, 1976; Hill, 1983). It is here reported for the first time feeding on a new plant host in South Africa, namely Agave salmiana Otto ex Salm-Dyck subsp. salmiana. This species of agave has been reported as a host for Scyphophorus acupunctatus in its native Mexico (e.g. Hernández et al., 2006), though only within the last four decades (Vaurie, 1971). As far as could be ascertained $A$. salmiana has not been reported as a host for the pest elsewhere.

The South African sisal industry experiences fairly regular and occasional serious outbreaks of $S$. acupunctatus, where this pest is known in Afrikaans as the 'sisalsnuitkewer' or 'sisalkalander' (Walters et al., 1989). Despite the severity of infections on sisal, no pesticides have yet been registered in South Africa against this pest (Annecke \& Moran, 1982; Krause et al., 1996; Anon., 2007). As a pest management alternative, recent work on pheromones produced by males of
S. acupunctatus indicates the potential use of these aggregation-inducing volatiles and also other chemical attractants obtained from agaves in mass-trapping programmes (Altuzar et al., 2007; Ruiz-Montiel et al., 2008).

\section{The plant host}

Agave salmiana Otto ex Salm-Dyck subsp. salmiana (Agavaceae) is a slow-growing century plant from Mexico that will in time produce a massive rosette consisting of large, dark green, boatshaped leaves (Figure 1). It is a monocarpic, multi-annual that usually flowers after between 10 to 15 years. The species suckers freely from the base, but much more slowly than the better known and locally naturalized Agave americana L. (Smith \& Mössmer, 1996). The inflorescence consists of a thick, robust pole that supports a fairly short, branched inflorescence that is pyramidal in shape (Figure 2). This at once separates it from $A$. americana which has a tall, elongated inflorescence.

Taxonomically, A. salmiana is widely regarded as consisting of three subspecies, two of which [the typical one and subspecies ferox (K.Koch) Gentry] are cultivated in South Africa. Although not known to be naturalized in southern Africa, this species has invaded elsewhere, for example the Iberian Peninsula, which has a Mediterranean climate similar to that of South Africa's southwestern Cape (Smith \& Figueiredo, 2007).

\section{The weevil}

The genus Scyphophorus Schönherr, 1838 (Coleoptera: Curculionidae) originates from the New World. It has two species that are commonly known as 'yucca weevil' (Scyphophorus yuccae Horn, 1873) and 'sisal weevil', 'sisal snout weevil', or 'agave snout weevil' (Scyphophorus acupunctatus Gyllenhal, 1838) (Vaurie, 1971). The two are distinguished on several characters (see Walker, 2008a, 2008b) of which the most easily observed is the shorter and stouter snout of $S$. acupunctatus (Figure 3) as opposed to the longer, narrower snout of S. yuccae. Adult agave snout weevils are large, up to $15 \mathrm{~mm}$ long, and black.

Scyphophorus acupunctatus is native to the southwestern U.S.A., Mexico, including Baja California, and Central America (Pott, 1975). It has been widely introduced to many parts of the world, including South Africa and eastern Africa, where Agave sisalana is grown as a source of natural fibres (Woodruff \& Pierce, 1973; Hill, 2008).

In South Africa, S. acupunctatus was collected on a cultivated specimen of Agave salmiana subsp. salmiana in a domestic garden in Pretoria, 
Gauteng Province. The garden has about 50 different species of Agave in cultivation, but S. acupunctatus was collected on Agave salmiana only. The weevil infected suckers of the specimen and not the mother plant, which is about eight years old, with leaves to $1.2 \mathrm{~m}$ in length.

The larvae of $S$. acupunctatus burrow into the heart of an agave plant, ingesting plant tissue en route. This destructive process is difficult to detect as only small entry holes provide initial evidence of snout weevil presence. These apertures are usually situated towards the base of the spear-like central cluster of unopened leaves in the agave rosette. Adults bore into the fleshy centre of the plant above the crown, where eggs are laid (Waring \& Smith, 1986). Detection usually occurs only after the plants lose vigor, by which time the host has been severely mined internally. Secondary fungal or bacterial rots occur in addition to feeding damage (Waring \& Smith, 1986; Solís-Aguilar et al., 2001). If such a plant is dissected, infestation is evidenced by galleries made by larval and adult weevils in the fleshy leaves (Figure 4) and bole of the plant (Waring \& Smith, 1986). Each female beetle can lay on average between 25 and 50 eggs, with as many as 60 eggs produced during a three month period (Harris, 1936; Hill, 2008). After the eggs hatch, larvae feed on the fleshy inner parts of the plant and when ready to pupate they tunnel down into the roots, within which they construct cocoons using host plant fibers (Pott, 1975). Cocoons are also readily found at the bases of leaves of certain agave species (Waring \& Smith, 1986). The next generation of weevil adults eventually exits the plant to infect other plants. When first reported in the fields of blue agave (Agave tequilana F.A.C.Weber 'Azul'), this plague was called 'gangrene of the blue agave' (Solís-Aguilar et al., 2001; Valenzuela-Zapata \& Nabhan, 2003).

Voucher specimen: South Africa. Gauteng Province, Pretoria. 2528 (-CB); 254'01.04” S $28^{\circ} 16^{\prime} 09.74^{\prime \prime}$ E. Domestic garden in Weavind Park. 29 December 2008. G.F. Smith \& E. Figueiredo 10. Voucher specimen [G.F. Smith \& E. Figueiredo 10] deposited at the Ditsong: National Museum of Natural History (formerly the Transvaal Museum), Pretoria.

Agave salmiana is one of the main sources of the drink pulque (Gonçalves de Lima, 1990). After the emerging inflorescence is removed early on, pulque is obtained from fermenting the juice obtained from the centres of the rosettes of A. salmiana, A. atrovirens Karw. ex Salm-Dyck

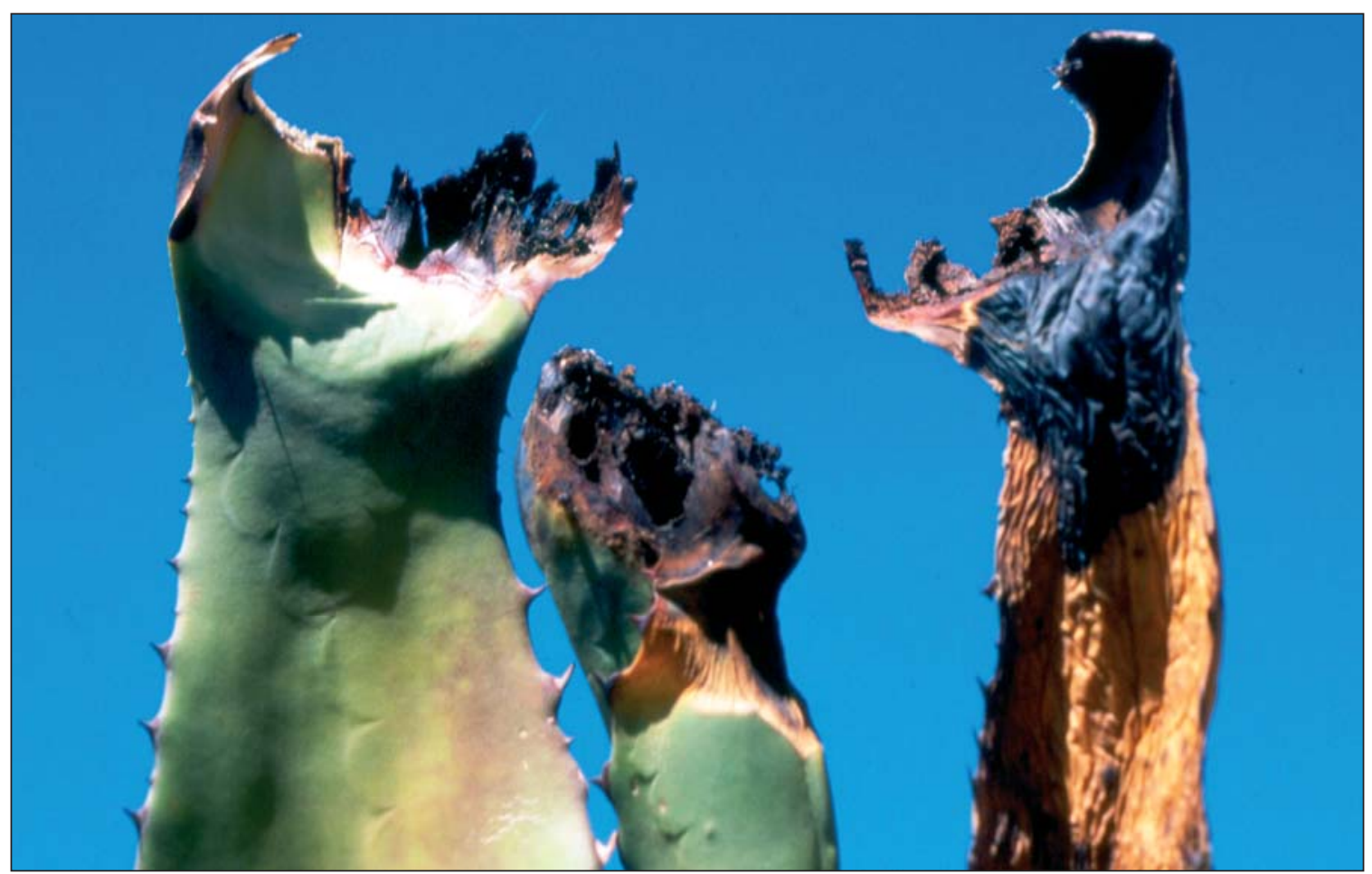

Figure 4. Damage to the basal parts of the leaves of Agave salmiana following infestation of Scyphophorus acupunctatus. Photo: Gideon F. Smith. 
and A. mapisaga Trel. Agave salmiana hearts are also used for the distillation of mescal, of which the commercially popular and widely consumed tequila is one type (Valenzuela-Zapata, 1994; Aguirre Rivera et al., 2001). It is noteworthy that the maguey 'worm' or red 'worm' often found at the bottom of bottles of commercially available mescal - tequila never contains a worm - is the caterpillar of Hypopta agavis Blázquez (Lepidoptera: Cossidae), another pest of Agave species (Quiroz Márquez, 1997).

\section{Other plant hosts}

Scyphophorus acupunctatus is known as a pest of several species of Agavaceae and Dracaenaceae (Vaurie, 1971; Solís-Aguilar et al., 2001; RuizMontiel et al., 2003; Aquino Bolaños et al., 2007; Hill, 2008; Valdéz et al., 2010). It attacks many useful species of Agave, such as those used for fibre production (A. sisalana, sisal; A. fourcroydes Lem., henequen), beverages (A. tequilana F.A.C.Weber, tequila) or ornamental purposes (A. americana) (EPPO, 2002). It is also found in species of the related genera Furcraea Vent., Yucca [e.g. Y. aloifolia L., Y. elephantipes Regel ex Trel., Y. glauca Nutt.], Beaucarnea, Dasylirion Zucc. (D. longissimum Lem.) (EPPO, 2002) and recently on Polianthes tuberosa L., which is sometimes treated as a species of Agave (Lavin et al., 2002). That it is also known to infest members of Dracaena Vand. ex L. [D. draco L.] (Vaurie, 1971; EPPO, 2002) is unsurprising, given the quite close affinity of the Dracaenaceae to the Agavaceae (Bogler \& Simpson, 1996). To date the weevil has been reported from eastern and South Africa, South America, Europe (including its Mediterranean Basin), northern Asia, south and southeast Asia, Australia, Hawaii, mainland U.S.A. and Canada (Vaurie, 1971; Hill, 2008; Walker, 2008b; Setliff \& Anderson, 2011).

\section{Acknowledgements}

We are grateful to Dr Helmuth Zimmermann of Pretoria, South Africa, for literature and helpful discussions on agave weevil infestations; Ms K. Swanepoel for kindly providing current information on the state of South African agave industries; Mr Riaan Stals of South Africa's National Insect Collection, Agricultural Research Council, Pretoria, for positively identifying material of the agave weevil; Ms Lesley Henderson and Ms Hildegard Klein of the Agricultural Research Council, Pretoria, South Africa, for information on the registration of pesticides. An anonymous referee is thanked for scholarly advice on improving the manuscript.

\section{References}

Aguirre Rivera, J.R., Salazar, H.C. \& Flores Flores, J.L. (2001). El maguey mezcalero potosino. Universidad Autónoma de San Luis Potosí, San Luis Potosí.

Altuzar, A., Malo, E.A., González-Hernández, H. \& RoJAs, J.C. (2007). Electrophysiological and behavioural responses of Scyphophorus acupunctatus (Col., Curculionidae) to Agave tequilana volatiles. J. Appl. Entomol. 131: 121-127.

Annecke, D.P. \& Moran, V.C. (1982). Insect and mite pests of cultivated plants in South Africa. Butterworths, Durban.

ANON. (2007). A guide for the control of plant pests. 40th Edition. National Department of Agriculture, South Africa.

Anon. (2009). Veilings/Auctions. Tequilafabriek buite Graaff-Reinet te koop. Die Burger Saturday 2 May 2009: 6.

Aquino Bolaños, T., Iparraguirre Cruz, M.A. \& RuIZ VEGA, J. (2007). Scyphophorus acupunctatus (=interstitialis) Gyllenhal (Coleoptera: Curculionidae). Pest of agave mezcalero: losses and damage in Oaxaca, México. UDO Ag. (Venezuela) 7: 175-180.

Biggs, D. (2004). Aribba Agava! The Karoo tequila. Good Taste January/February 2004: 86-90.

Bogler, D.J. \& Simpson, B.B. (1996). Phylogeny of Agavaceae based on ITS rRNA sequence variation. Am. J. Bot. 83: 1225-1235.

EPPO. (2002). European and Mediterranean Plant Protection Organization Reporting Service 3: 2002/046.

EPPO. (2008a). European and Mediterranean Plant Protection Organization Reporting Service 11: 2008/220.

EPPO. (2008b). European and Mediterranean Plant Protection Organization Reporting Service 9: 2008/179.

Germain, J.F., Ramel, J.M., Maury, A. \& Blanchon, F. (2008). Premier signalement en France d'un coléoptère ravageur des agaves. PHM-Revue Horticole no. 505: 34-36.

Gonçalves de Lima, O. (1990). Pulque, balché y pajauaru en la etnobiología de las bebidas y de los alimentos fermentados. Fondo de Cultura Económica, S.A. de C.V., México City, D.F.

HARRIS, W.V. (1936). The sisal weevil. E. Afr. Agric. For. J. 22: 114-126.

Hernández, R.M.C., Gutiérrez, O.M., Aldana, L.L. \& VALDÉS, E.MA.E. (2006). Fecundity of the sisal weevil, Scyphophorus acupunctatus (Coleoptera: Curculionidae), on Polianthes tuberosa (Liliales: Agavaceae). Fla. Entomol. 89: 518-520. 
HiLl, D.S. (1983). Agricultural insect pests of the tropics and their control. Cambridge University Press, Cambridge.

Hill, D.S. (2008). Pests of crops in warmer climates and their control. Springer, Berlin.

Krause, M., Nel, A. \& Ramautar, N. (1996). A guide to the use of pesticides and fungicides in the Republic of South Africa. 37th Edition. National Department of Agriculture, Pretoria.

Lavin, M.C., Gomez, V.R.C., BRito, R.E., Llanos, L.A., \& Estrada, M.E.V. (2002). Scyphophorus acupunctatus (Coleoptera: Curculionidae) attacking Polianthes tuberosa (Liliales: Agavaceae) in Morelos, Mexico. Fla. Entomol. 85: 392-393.

Potт, J.N. (1975). A Yucca borer, Scyphophorus acupunctatus, in Florida. Proc. Fla. State Hortic. Soc. 1975: 414-416.

Property24. (2008). Buy your own tequila factory. Commercial Property Specialists. http://ww w commercial - property. co.za/2201_news_Buy-your-own-Tequilafactory.html [Posted 21 November 2008. Accessed 1 July 2011].

Quiroz Márquez, J. (1997). Mezcal. Origin, elaboration and recipes. Codice Ediciones Mexicanas, S.A. de C.V., Mérida.

Ruiz-Montiel, C., Garcia-Coapio, G., Rojas, J.C., Malo, E.A., Cruz-López, L., Del Real, I. \& GONZÁLEZ-HERNÁNDEZ, H. (2008). Aggregation pheromone of the agave weevil, Scyphophorus acupunctatus. Entomol. Exp. Appl. 127: 207-217.

Ruiz-Montiel, C., GonzÁlez-Hernández, H., Leyva, J., Llanderal-Cezares, C., CruzLóPEZ, L. \& RoJAs, J.C. (2003). Evidence of a male-produced aggregation pheromone in Scyphophorus acupunctatus Gyllenhal (Coleoptera: Curculionidae). J. Econ. Entomol. 96: 1126-1131.

Setlief, G.P. \& Anderson, J.A. (2011). First record of the agave snout weevil, Scyphophorus acupunctatus Gyllenhal (Coleoptera: Curculionidae: Dryophthorinae), in Puerto Rico. Insecta Mundi 152: 1-3.

Slabbert, A. (2007). Groenbou nie net 'n klomp strooi nie. Die Burger 15 June 2007: page number unknown.

Smith, G.F. \& Figueiredo, E. (2007). Naturalized species of Agave L. (Agavaceae) on the southeastern coast of Portugal. Haseltonia 13: 52-60.

Smith, G.F. \& Mössmer, M. (1996). FSA contributions 4: Agavaceae. Bothalia 26: 31-35.

Solís-Aguilar, J.F., González-Hernández, H.,
Leyva-VÁzquez, J.L., Equihua-Martínez, A., Flores-Mendoza, F.J. \& Martínez-Garza, A. (2001). Scyphophorus acupunctatus Gyllenhal, an agave tequilero pest in Jalisco, México. Agrociencia 35: 663-670.

Stiemie, M. (1997). Tequila in 1998 op G-Reinet gemaak. Die Burger 15 September 1997.

Sutherland, P.C. (1900). III.-Botanic Garden, Durban. Kew Bull. 1900: 12-15.

Valenzuela-Zapata, A.G. (1994). El agave tequilero: su cultivo e industrialización. Monsanto, Zapopan.

ValenZuela-Zapata, A.G. \& NABhan, G.P. (2003). Tequila! A natural and cultural history. The University of Arizona Press, Tucson.

VAldÉs, E. MA.E., HeRnández, R.M.C., GuTiÉrReZ, O.M. \& ALDANA, L.L. (2010). Determination of the life cycle of Scyphophorus acupunctatus (Coleoptera: Curculionidae) under laboratory conditions. Fla. Entomol. 93: 398-402.

VAURIE, P. (1971). Review of Scyphophorus (Curculionidae: Rhynchophorinae). Col. Bull. 25: $1-8$.

VerbeeK, W.A. (1976). Annual report for the period 1 July, 1974 to 30 June, 1975. Report of the Secretary for Agricultural Technical Service, South Africa. Pp. 229. (Abstract.)

WALKer, K. (2008a). Yucca weevil (Scyphophorus yucca). Pest and Diseases Image Library. http://www.padil.gov.au/pests-anddiseases/Pest/Main/135994 [Accessed 1 July 2011].

WaLker, K. (2008b). Sisal weevil (Scyphophorus acupunctatus). Pest and Diseases Image Library. http://www.padil.gov.au/pests-anddiseases/Pest/Main/135993 [Accessed 1 July 2011].

WARING, G.L. \& SMith, R.L. (1986). Natural history and ecology of Scyphophorus acupunctatus (Coleoptera: Curculionidae) and its associated microbes in cultivated and native agaves. Ann. Entomol. Soc. Am. 79: 334-340.

Walters, S.S., Drinkwater, T.W. \& Eulitz, E.G. (1989). Leaf eating beetles. In MyBurgh, A.C. (ed.). Crop pests in southern Africa. Vol. 4. Field crops and pastures. Bulletin 416. Department of Agriculture and Water Supply, Pretoria.

Woodruff, R.E. \& Pierce, W.H. (1973). Scyphophorus acupunctatus, a weevil pest of Yucca and Agave in Florida (Coleoptera: Curculionidae). Entomol. Circ. (Florida Dept. Agr. \& Consumer Services, Division of Plant Industry) 135: 1-2.

Agave salmiana has since been recorded as established in South Africa. See Smith, G.F. \& Figueiredo, E. (2012). A further species of Agave L., A. salmiana Otto ex Salm-Dyck (subsp. salmiana) var. salmiana (Agavaceae), naturalised in the Eastern Cape Province of South Africa. Bradleya 30: 179-186. 